\title{
Influence of habitat structure on Pristimantis species (Anura: Craugastoridae) in a bamboo-dominated forest fragment in southwestern Amazonia
}

\author{
Jhon Jairo López-Rojas ${ }^{1}$, Moisés Barbosa Souza², and Elder Ferreira Morato \\ ${ }^{1}$ Universidade Federal do Acre, Programa de Pós-Graduação em Ecologia e Manejo de Recursos Naturais, Laboratório de \\ Herpetologia (HerPet), 69915-900, Rio Branco, AC, Brazil. E-mail: lopezrojasjj@gmail.com. \\ ${ }^{2}$ Universidade Federal do Acre, Centro de Ciências Biológicas e da Natureza, Laboratório de Herpetologia (HerPet), 69915- \\ 900, Rio Branco, AC, Brazil. \\ ${ }^{3}$ Universidade Federal do Acre, Centro de Ciências Biológicas e da Natureza, 69915-900, Rio Branco, AC, Brazil.
}

\begin{abstract}
Influence of habitat structure on Pristimantis species (Anura: Craugastoridae) in a bamboo-dominated forest fragment in southwestern Amazonia. Structural and determinate factors for the composition of assemblages of species are diverse. Two theories attempt to explain the pattern of species composition in assemblies using different approaches-i.e., Niche Theory and Neutral Theory. Anurans have complex responses to habitat structure. Species of Pristimantis are good indicators for conservation because they are organisms with direct development. The effect of habitat structure on species of Pristimantis in a bamboo-dominated remnant forest located in southwestern Amazonia is analyzed herein. Active visual and auditory searches in 10 plots of the Biodiversity Research Program (PPBio) were conducted between November 2012 and May 2013. Four hundred and sixty individuals of five species were recorded: Pristimantis altamazonicus, $P$. diadematus, $P$. fenestratus, $P$. reichlei, and $P$. skydmainus. Neither spatial distance nor the structure of the habitat of the plots affected the composition of Pristimantis. The first axis of PCA explained 45.6\% variation of the characterization habitat structure, correlated significantly with the number of Pristimantis, species increasing with trees between $10 \leq \mathrm{dbh}<30 \mathrm{~cm}$ and decreased with density of bamboo. The increase in litter depth and canopy cover influenced in the occurrence of $P$. reichlei, the occurrence of $P$. skydmainus decreased with increased density of bamboo and trees dbh $\geq 30$ $\mathrm{cm}$ and the occurrence of $P$. diadematus decreased relative to increased canopy cover. Pristimantis diadematus and $P$. skydmainus were the most restricted species in terms of habitat and were especially susceptible to bamboo density.
\end{abstract}

Keywords: anurans, bamboo density, habitat structure, Neutral Theory, Niche Theory, northern Brazil, probability of occurrence.

Received 19 August 2014.

Accepted 11 December 2014.

Distributed June 2015. 


\begin{abstract}
Resumo
Influência da estrutura do habitat sobre espécies de Pristimantis (Anura: Craugastoridae) em um fragmento florestal dominado por bambu no sudoeste da Amazônia. Diversos são os fatores estruturais e determinantes da composição das assembleias de espécies. Duas teorias tentam explicar o padrão de composição das espécies em assembleias utilizando abordagens distintas: Teoria do Nicho e Teoria Neutra. Os anuros apresentam respostas complexas à estrutura do habitat. Espécies de Pristimantis constituem-se em bons indicadores para a conservação porque são organismos com desenvolvimento direto. Analisamos aqui o efeito da estrutura do habitat sobre espécie de Pristimantis em um remanescente florestal dominado por bambu, localizado no sudoeste da Amazônia. Entre novembro de 2012 e maio de 2013, realizamos por busca ativa visual e auditiva em 10 parcelas do Programa de Pesquisa em Biodiversidade (PPBio). Foram registrados 460 indivíduos de cinco espécies: Pristimantis altamazonicus, $P$. diadematus, $P$. fenestratus, $P$. reichlei e $P$. skydmainus. A composição de Pristimantis não foi afetada pela distância espacial ou pela a estrutura do habitat das parcelas. O primeiro eixo da PCA explicou 45,6\% da variação da caracterização da estrutura do habitat, significativamente correlacionado com o número de espécies de Pristimantis, aumentando com árvores entre $10 \leq \mathrm{DAP}<30 \mathrm{~cm}$ e diminuindo com a densidade de bambus. O aumento da profundidade da serapilheira e cobertura do dossel influenciou na ocorrência de $P$. reichlei, a ocorrência de $P$. skydmainus diminuiu com o aumento da densidade de bambu e de árvores com DAP $\geq 30 \mathrm{~cm}$ e a ocorrência de $P$. diadematus diminuiu com o aumento da cobertura do dossel. Pristimantis diadematus e P. skydmainus foram as espécies mais restritas em termos de habitat e mostraram-se especialmente suscetíveis à densidade de bambu.
\end{abstract}

Palavras-chave: anuros, densidade de bambu, estrutura do hábitat, norte do Brasil, probabilidade de ocorrência, Teoria do Nicho, Teoria Neutra.

\section{Introduction}

Several ecological theories have been developed to explain the distribution and abundance of species, and thus, the composition of assemblages or communities (Ricklefs and Schluter 1993). For example, the Neutral Theory (Hubbell 2001) assumes that ecological communities are structured by drift (demographic stochasticity), with all individuals in an assembly having equal probability of reproducing, dying, or migrating (Hubbell 2005). Therefore, sites with similar habitats or environments will tend to support similar assemblages (Gaston and Chown 2005). In contrast, Niche Theory (Macarthur and Levins 1964, Kneitel and Chase 2004) hypothesizes that to coexist in a community, species have trade-offs-i.e., specialization in obtaining a certain type of resource that usually is accompanied by a decrease in efficiency with respect to another resource (Mikkelson 2005, Giacomini 2007).
The southwestern Amazon is known for extensive plant cover $\left(165,000 \mathrm{~km}^{2}\right)$ of bamboodominated open forest Guadua weberbaueri (Smith and Nelson 2011) and currently undergoing a process of fragmentation and loss of vegetation (Baitz et al. 2008). Several studies in this forest type have shown that bamboo affects the structure and dynamics of forest structure (Griscom and Ashton 2003, Silveira 2005, Griscom et al. 2007). Such habitat changes can influence amphibian community parameters, such as richness and abundance (Von May et al. 2010).

As a rule, amphibians require aquatic habitats for oviposition and tadpole development (Duellman and Trueb 1994, Wells 2007). However, in the genus Pristimantis, terrestrial eggs undergo direct development (Pombal and Haddad 2007); because they are vulnerable to dehydration and desiccation, survival depends the availability of optimal conditions for oviposition in the forests (Wake 1991, Toral et al. 2002). Several environmental factors related 
to the habitat structure (e.g., leaf litter depth, vegetation density, and basal area) are important for abundance and richness of anurans (including Pristimantis) in the leaf litter in Amazonian tropical forests (Pearman 1997, Menin et al. 2007, Van Sluys et al. 2007, Blair and Doan 2009, Tsuji-Nishikido and Menin 2011). Little is known about effect of the presence or absence of bamboo that might provide an additional microhabitat for frogs, on anuran community composition (Blair and Doan 2009). For example, Pristimantis bambu is associated with mountane bamboo-dominated forests (Chusquea sp.) in southeastern Ecuador (Arteaga-Navarro and Guayasamin 2011).

The study of Pristimantis is challenging owing to the high diversity of the genus. There are 473 neotropical species and 38 of these occur in Brazil (Frost 2014, Segalla et al. 2014). Intraspecific variation, along with the paucity of distinguishable external morphological characters among species, has limited investigations of population trends, ecology, and distribution (Guayasamin and Funk 2009). In southwestern Amazonia, few studies have investigated environmental variables that influence this genus (Blair and Doan 2009). Thus, we intend use niche and neutral theories to: (1) identify the environmental variables related to the main habitat-structure gradients in a bamboodominated forest fragment; (2) test whether species composition of Pristimantis is related to habitat structure gradients or spatial structure of the sampling units; (3) test whether habitatstructure gradients explain the Pristimantis species richness and abundance; and (4) identify the environmental variables that explain the occurrence of species of Pristimantis.

\section{Materials and Methods}

\section{Study Area}

The study was conducted in a forest remnant known as Fazenda Experimental Catuaba (hereafter called Catuaba) $\left(10^{\circ} 04^{\prime} \mathrm{S}, 67^{\circ} 37^{\prime} \mathrm{W}\right)$, located in municipality of Senador Guiomard,
Acre State, Brazil (Figure 1). Catuaba comprises 1200 ha of mainly terra firma forest (upland) with patches of open forest dominated by arborescent bamboo Guadua weberbaueri. There are some 15-30-yr-old secondary forests and pastures along the edges of the forest fragment. The forest is characterized by a closed canopy 20-40 m high. The most abundant canopy trees are Hevea brasiliensis (Euphorbiaceae), Bertholletia excelsa (Lecythidaceae), and Carapa guianensis (Meliaceae); the understory is closed, with a predominance of vines and stems of the bamboo G. weberbaueri (Silveira 2005). The rainy season spans October-April and the rest of the year is dry (Duarte 2006). The mean annual temperature is $17-33^{\circ} \mathrm{C}$ and the mean annual rainfall is $1958 \mathrm{~mm}$ (Duarte 2006).

\section{Data Collection}

Anurans were sampled and environmental variable measured in 10 plots, which were installed by the Biodiversity Research Program (PPBio) at Catuaba; the plots are separated by $500 \mathrm{~m}$ and distributed along a 5-km trail. The plots are $250 \mathrm{~m}$ long and $4 \mathrm{~m}$ wide, and follow the contour of the ground from the start point of each plot to minimize the variation in the topography (Magnusson et al. 2005). Fieldwork was conducted for 70 days during the rainy season between November 2012 and May 2013 ( 2 monthly visits consisting of 5 days each).

Five environmental variables were recorded to characterize the habitat structure (Table 1). The plots were quantified according to tree size, as measured by diameter at breast height $(\mathrm{dbh})$; (1) all trees with $10 \leq \mathrm{dbh}<30$ on a $250 \times 20$ $\mathrm{m}$ tract, and (2) trees with $\mathrm{dbh} \geq 30 \mathrm{~cm}$ on a $250 \times 40 \mathrm{~m}$ tract (including the range of $250 \times$ $20 \mathrm{~m}$ ). (3) All bamboo $\geq 2 \mathrm{~m}$ high within $2 \mathrm{~m}$ on either side of the midline of the plot was counted. (4) The depth of leaf litter was measured three times during the study, and recorded $5 \mathrm{~m}$ from the plot centerline at five locations at 50-m intervals from one another. At each point, five measurements were taken in an area of $1 \times 1 \mathrm{~m}$, 


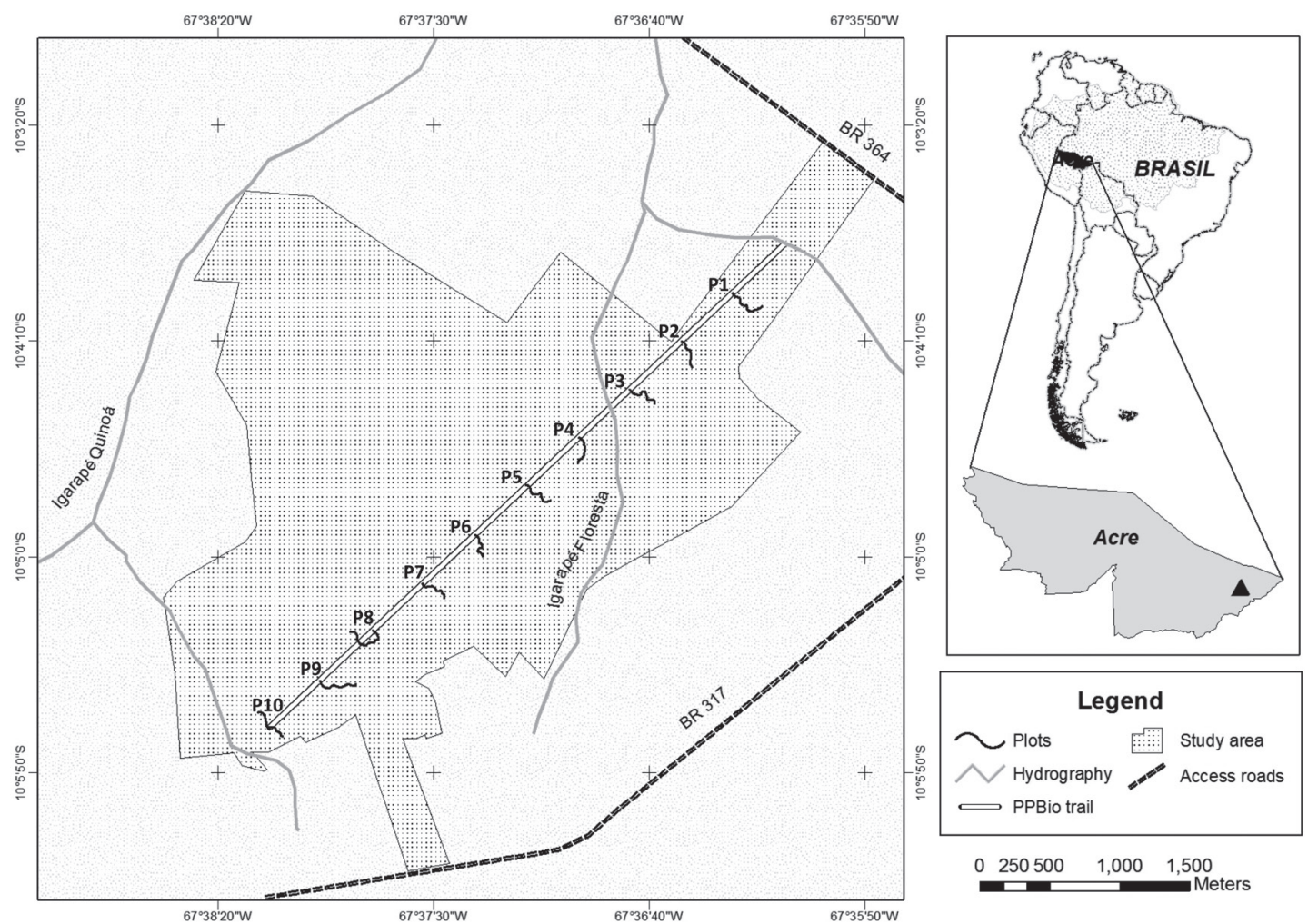

Figure 1. Location of the Catuaba, Senador Guimard, Acre, Brazil. Abbreviations (P1 to P10) represent the identification number of each plot.

(on street corners and in the center) with digital calipers (Tools ${ }^{\circledR}$ Club $200 \mathrm{~mm}$ ); we used mean leaf litter depth for each plot in analyses. (5) Canopy cover $(\%)$ was estimated from photographs made at five points separated by $50 \mathrm{~m}$ on each tract. A Sony® Cyber Shot (8.1 mega pixels) equipped with a 58-mm fisheye lens was placed 1 $\mathrm{m}$ above the ground, and photographs were taken between 06:30 and 07:30 h, and analyzed with Gap Light Analyzer Ver. 2.0 (Frazer et al. 1999). The mean of the five measurements represented the canopy cover of the plot.

The species of Pristimantis were documented by visual and auditory searches (Crump and Scott 1994, Zimmerman 1994). Two persons searched for anurans for about $90 \mathrm{~min}$ in each plot between
17:00 and 23:00 h. Each animal was identified by comparison with specimens deposited in the collection of UFAC or by consulting specialized references (Heyer and Hardy 1991, Duellman and Lehr 2009, Padial and De la Riva 2009, Souza 2009). Specimens collected were euthanized and fixed following the protocol of Callefo (2002) and deposited in the Herpetological Collection of UFAC. Taxonomy of the species used in this study follows Frost (2014).

\section{Data Analysis}

Analyses were performed in RStudio Version 0.96.331 (R Development Core Team 2012) with Vegan (Oksanen et al. 2011). The number 
Table 1. Variables of the habitat forest structure in the 10 plots sampled at Catuaba, Senador Guimard, Acre, Brazil. Results are expressed as mean \pm SD.

\begin{tabular}{lccccc}
\hline Plot & \multicolumn{5}{c}{ Variables } \\
\cline { 2 - 6 } & $\begin{array}{c}\text { Leaf litter depth } \\
(\mathrm{cm})\end{array}$ & Bamboo/0.1 ha & $\begin{array}{c}\text { Number of trees } 10 \leq \\
\text { dbh }<30 / 0.5 \text { ha }\end{array}$ & $\begin{array}{c}\text { Number of trees } \\
\geq 30 / 1 \text { ha }\end{array}$ & $\begin{array}{c}\text { Canopy cover } \\
(\%)\end{array}$ \\
\hline P1 & $17.2 \pm 8.7$ & 32 & 134 & 32 & $76.7 \pm 10.1$ \\
P2 & $42.5 \pm 24.6$ & 314 & 64 & 42 & $78.5 \pm 7.3$ \\
P3 & $38.7 \pm 15.1$ & 138 & 135 & 51 & $80.9 \pm 4.9$ \\
P4 & $33.1 \pm 15.3$ & 14 & 183 & 81 & $80.8 \pm 4.5$ \\
P5 & $48.5 \pm 16.3$ & 0 & 118 & 75 & $80.6 \pm 9.7$ \\
P6 & $36.2 \pm 16.0$ & 56 & 235 & 31 & $83.4 \pm 3.9$ \\
P7 & $33.6 \pm 12.8$ & 144 & 133 & 42 & $80.9 \pm 6.9$ \\
P8 & $35.8 \pm 12.5$ & 30 & 175 & 105 & $82.8 \pm 4.7$ \\
P9 & $30.9 \pm 15.7$ & 48 & 104 & 43 & $75.7 \pm 5.6$ \\
P10 & $33.2 \pm 17.9$ & 246 & 63 & 65 & $63.6 \pm 22.6$ \\
\hline
\end{tabular}

of individuals was estimated by visual and auditory encounters recorded in each plot.

To identify and characterize the main habitatstructure gradients, a correlation Principal Component Analysis (PCA; "prcomp" function in R) was applied to extract synthetic variables (principal components) from the linear relation between the environmental variables (by reduce dates dimensionality were standardized using standard deviation with "scale $=\mathrm{T}$ " argument). Principal components represent gradients in habitat structure and explain a certain percentage of the original environmental data (Borcard et al. 2011). The main principal components ( $\mathrm{PCs}-\mathrm{PC} 1$ and PC2) were selected based on the eigenvalues and the percent of explained variance (Table 2).

To test the influence of distance among plots and habitat structure on the species composition of Pristimantis, we evaluated the dissimilarity between all pairs of variables. Thus, three matrices (with "vegdist" function) (Legendre and Legendre 1998) were constructed. For habitat structure, the five variables were used to construct a matrix with the dissimilarity index of Bray-Curtis (with "Bray" method). For distances between plots, the Euclidean distance (with "Euclidian" method) was used to calculate straight distances between each sampling unit to create a matrix of spatial distances among plots. To construct the species composition matrix of Pristimantis, the number of individuals recorded in each plot by Bray-Curtis distance was used. The Mantel test (Manly 1994) was used to correlate the three matrices of Pristimantis assemblage composition and dissimilarity in relation to habitat structure of the plots and the 
Table 2. PCA loadings of the habitat forest structure variables in the 10 plot sampled at Catuaba, Senador Guimard, Acre, Brazil.

\begin{tabular}{lccccc}
\hline Variables & PC1 & PC2 & PC3 & PC4 & PC5 \\
\hline Leaf litter depth $(\mathrm{cm})$ & 0.024 & -0.777 & 0.381 & -0.285 & -0.412 \\
Bamboo & -0.554 & -0.166 & 0.361 & 0.723 & 0.112 \\
Number of trees $10 \leq \mathrm{dbh}<30 / 0.5$ ha & 0.595 & 0.177 & 0.108 & 0.531 & -0.567 \\
Number of trees $\geq 30 / 1$ ha & 0.205 & -0.570 & -0.687 & 0.335 & 0.220 \\
Canopy cover $(\%)$ & 0.544 & -0.112 & 0.491 & 0.042 & 0.669 \\
Explicated variance $(\%)$ & 45.57 & 26.91 & 18.05 & 5.48 & 3.99 \\
\hline
\end{tabular}

matrix of spatial distance among plots (with "mantel" function). We used 999 randomizations to test the significance of correlations (with "permutations = 999" argument).

To test whether habitat structure explains the number of species and abundance of Pristimantis, the relationship between the scores from the retained PCs (PC1 and PC2) and the community parameters were examined with linear regression.

To determine the relationship between habitat structure and species occurrence, we used logistic regression (with the "glm" function), with the species that occurred in at least $50 \%$ of the plots.

\section{Results}

During 70 days of sampling, 460 individuals of five species of the genus Pristimantis were recorded in all plots. Of the five species, $P$. fenestratus was the most abundant and found in all plots, and $P$. altamazonicus was the least abundant and recorded in only three plots (Table $3)$.

The principal component analysis (PCA) indicates that the first two axes accounted for approximately $72.5 \%$ of the total variation of the set of variables of habitat structure (Table 2). The subsequent PCs were not used for further analysis because each accounted for only a low percentage of the variance.

The first component (PC1) accounts for $45.6 \%$ of the variation and is associated with positive values by the trees with $10 \leq \mathrm{dbh}<30$ and canopy coverage, and negatively with bamboo density. Whereas PC2 accounts for $26.9 \%$, litter depth and trees with $\mathrm{dbh} \geq 30$ are the variables negatively related to this PC (Figure 2).

The species composition of Pristimantis is not correlated to spatial distance $\left(r_{\text {mantel }}=0.186\right.$, $p=0.097, \mathrm{df}=43$ ) or the dissimilarity of the habitat structure among plots $\left(r_{\text {mantel }}=-0.060, p=\right.$ $0.637, \mathrm{df}=43$ ).

There is a positive correlation between the values of $\mathrm{PC} 1$ and number of species $\left(R^{2}=\right.$ $0.442, p=0,036$ ) (Figure 3A). However, PC1 is not correlated with the number of individuals $\left(R^{2}\right.$ $=0.058, p=0.499)$ (Figure 3B). Neither richness nor abundance is associated with PC2 values $\left(R^{2}\right.$ $\left.=0.217, p=0,175 ; R^{2}=0.153, p=0.264\right)$.

With regard to the occurrences of species of Pristimantis (Table 4), the probability of occurrence of $P$. diadematus is positively associated only with canopy cover $\left(\chi^{2}=4.982, p\right.$ $=0.026, \mathrm{df}=1)$. The probabily of the occurrence of $P$. reichlei increases with litter depth $\left(\chi^{2}=\right.$ 8.576, $p=0.003, \mathrm{df}=1)$ and canopy cover $\left(\chi^{2}=\right.$ 
Table 3. Number of individuals of Pristimantis registered in 10 plots at Catuaba, Senador Guimard, Acre, Brazil.

\begin{tabular}{|c|c|c|c|c|c|c|c|c|c|c|c|}
\hline \multirow{2}{*}{ Species } & \multicolumn{10}{|c|}{ Plot } & \multirow{2}{*}{$\begin{array}{c}\text { Total } \\
\text { number of } \\
\text { individuals }\end{array}$} \\
\hline & P1 & P2 & P3 & P4 & P5 & P6 & P7 & P8 & P9 & P10 & \\
\hline Pristimantis altamazonicus & & & & & 2 & 1 & 2 & & & & 5 \\
\hline Pristimantis diadematus & & & 7 & 2 & 11 & 6 & 6 & & & & 32 \\
\hline Pristimantis fenestratus & 15 & 26 & 46 & 16 & 40 & 52 & 44 & 28 & 23 & 45 & 335 \\
\hline Pristimantis reichlei & & 8 & 12 & 14 & 5 & 7 & 10 & 3 & & & 59 \\
\hline Pristimantis skydmainus & & & 3 & 17 & 4 & & & 1 & 4 & & 29 \\
\hline Number of individuals & 15 & 34 & 68 & 49 & 62 & 66 & 62 & 32 & 27 & 45 & 460 \\
\hline Number of species & 1 & 2 & 4 & 4 & 5 & 4 & 4 & 3 & 2 & 1 & 5 \\
\hline
\end{tabular}

12.203, $p<0.000$, df $=1$ ). The presence of $P$. skydmainus decreases with increasing density of bamboo $\left(\chi^{2}=3.707, p=0.054\right.$, $\left.\mathrm{df}=1\right)$, but is positively associated with the number of trees $\geq$ $30 \mathrm{~cm}\left(\chi^{2}=4.832, p=0.028, \mathrm{df}=1\right)$.

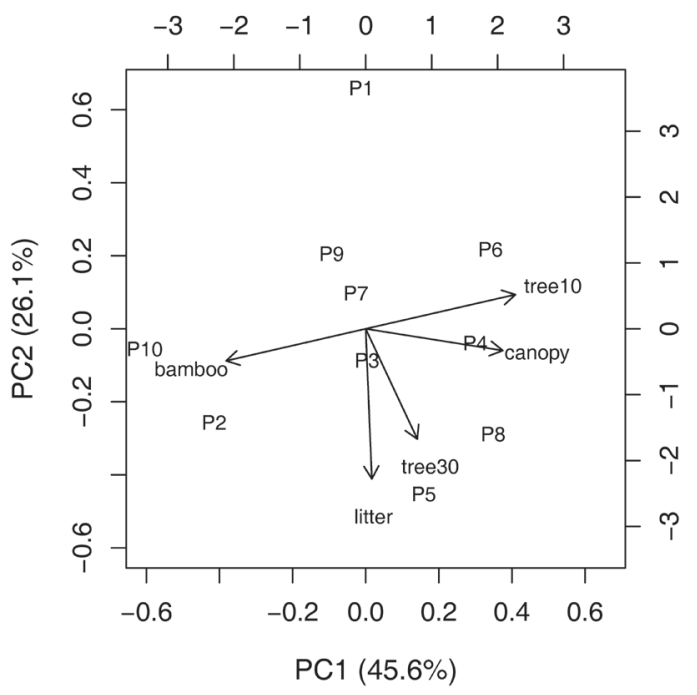

Figure 2. Projection of plots and variables on the first two PCA axes. Abbreviations (P1 to P10) represent the identification number of each plot.

\section{Discussion}

Whereas the niche theory best explains some of the observed patterns, in other cases, the neutral theory seems to be more appropriate (e.g., Cottenie 2005, Thompson and Townsend 2006). Our results demonstrate that composition dissimilarities among communities of Pristimantis is neither related to habitat variation or distances among plots. According to Legendre and Fortin (1989), spatial structure affects species composition, with geographically closer sites tending to have more similar assemblages than distant sites. Individuals differ in the probability of colonizing a given type of environment, owing to their ability to disperse and the effects of variation between environments, as well as environmental variable groups with similar characteristics that can differ according to species composition (Fauth et al. 1989). The fact that the dissimilaritie of species composition of Pristimantis is not correlated with the habitat-structure characteristics indicates that the niche theory does not explain the species composition. Thus, the distribution of Pristimantis, according to this 


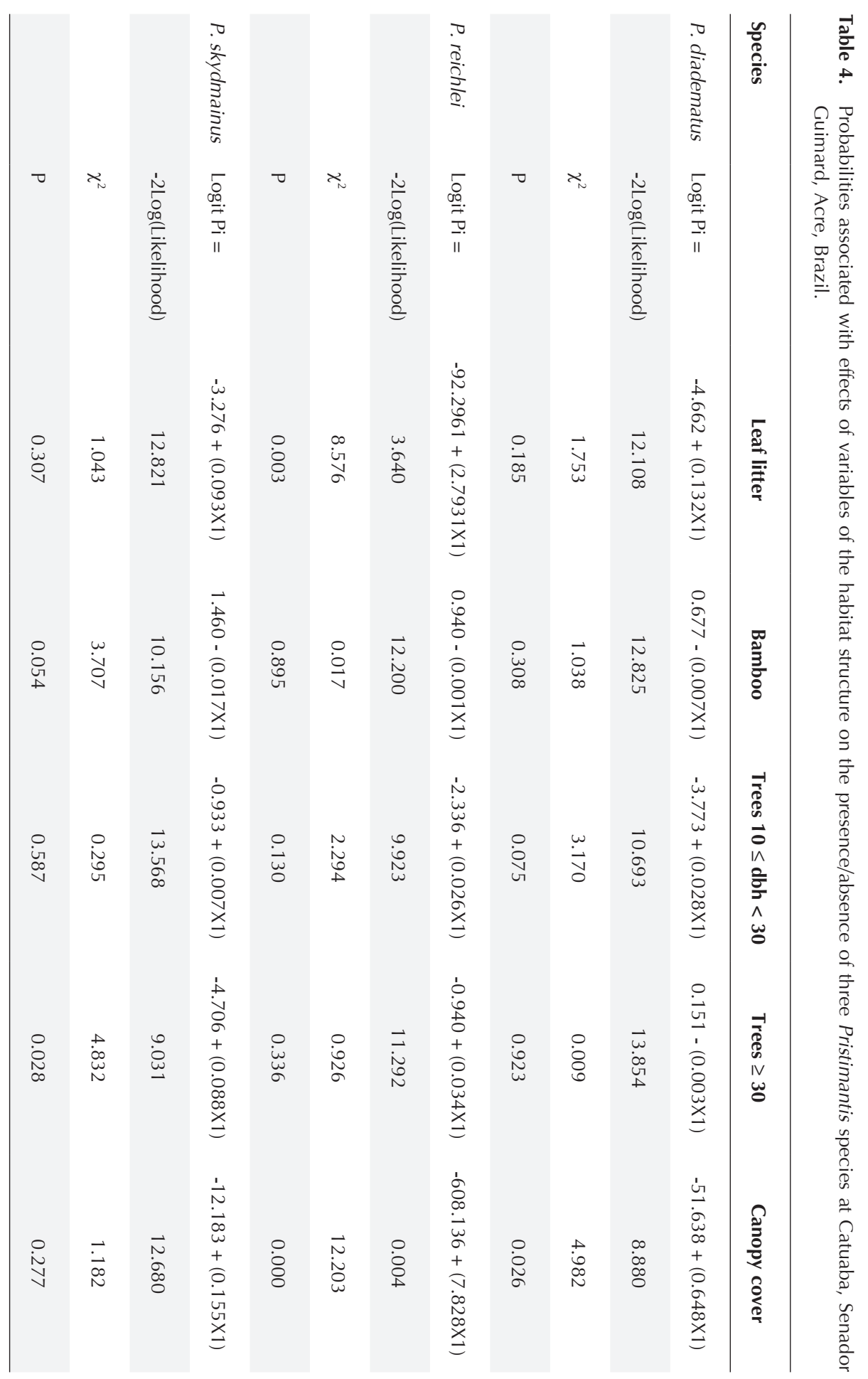



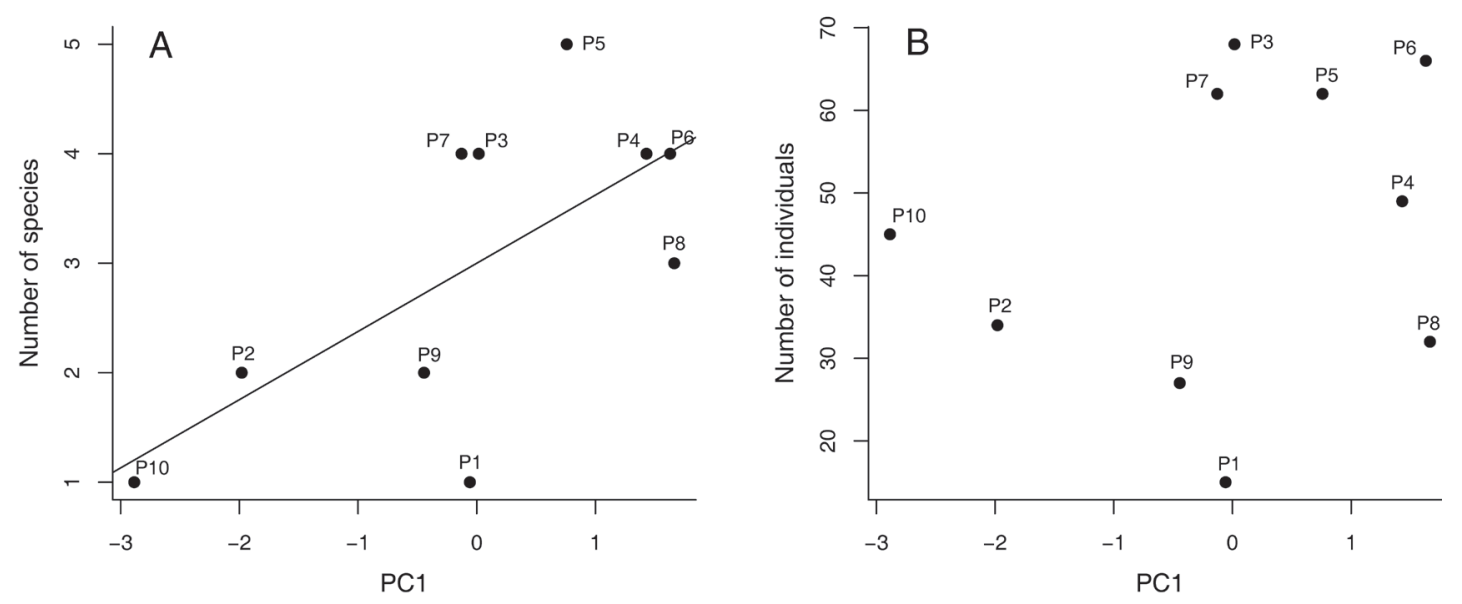

Figure 3. Relationship between the first principal component (PC 1) of the variables of habitat structure with the number of species $\left(R^{2}=0.442, p=0,036\right)(\mathbf{A})$, and number of individuals $\left(R^{2}=0.058, p=0.499\right)(\mathbf{B})$ of Pristimantis in 10 plots sampled at Catuaba, Senador Guimard, Acre, Brazil.

study, seems not to be influenced by local environmental conditions in bamboo-dominated forests in southwestern Amazonia. The lack of correlation between geographic distance and similarity of species composition of Pristimantis indicates that the pattern observed is not explained by neutral theory.

Research conducted at Catuaba suggests that the forest is in a regeneration process (beginning $30 \mathrm{yr}$ ago), and shows that plots with higher densities of bamboo had higher tree mortality and disturbance of vegetation by the wind both on the edges and insides of the fragments (Laurance et al. 1998, Castro et al. 2013, Medeiros et al. 2013), thereby implying reductions in density, canopy, and number of tree species (Griscom and Ashton 2003, Silveira 2005, Griscom et al. 2007). This partly explains our results with regard to the differences in habitat structure among plots affecting the number of species and occurrence of Pristimantis; in addition, it suggests that the distance from the edge of the plots in the bamboo-dominated fragment is another variable involved in the distribution of Pristimantis.
As the quantity of bamboo in the plots increases the number of species diminishes, paralleling the decrease of trees with $10 \mathrm{~cm}<$ $\mathrm{dbh}<30 \mathrm{~cm}$. P10 and P2 plots had a more open canopy, larger amounts of bamboo, and a considerable accumulation of leaf litter-all of which limit the occurrence of specialist species in this microhabitat (Cabrera-Guzmán and Reynoso 2012). The tendency of Pristimantis to be influenced by the areas of a more enclosed canopy has been documented by Pearman (1997). Other studies conducted in central Amazonia and in Costa Rica found no influence of tree diameter and canopy cover on the number of individuals and diversity of litter frogs (see Allmon 1991, Watling 2005 for data from other amphibian species) and Pristimantis (Blair and Doan 2009).

Currently, only 31 species of frogs are known to occur at Catuaba (Cardoso and Souza 1996), of which three are species of Pristimantis (Souza et al. 2008). With the addition of Pristimantis reichlei for Brazil (Sampaio and Souza 2010), there are six species of Pristimantis in the study area. According to Pearman (1997), the 
Pristimantis of tropical forests are sensitive to human disturbances and are indicators of environmentally healthy habitats; thus, they are excellent models for ecological experiments.

The occurrence of Pristimantis diadematus is positively influenced by increasing canopy cover, in agreement with the results shown in Pearman (1997). In addition, $P$. reichlei is influenced by litter depth, as is $P$. peruvianus (Blair and Doan 2009). The probability of the occurrence of $P$. skydmainus is favored by increasing density of trees with dhb $\geq 30 \mathrm{~cm}$. Menin et al. (2007) showed that the presence of $P$. ockendeni is associated with the number of trees. Marsh and Pearman (1997) showed that abundance of $P$. chloronotus is inversely correlated with the density of the understory, and Doan and Blair (2009) reported that $P$. peruvianus abundance is associated with tree diameter.

The results of this study and those of the other studies mentioned above revealed differences among the methods of quantification of litter characteristics (volume, depth, or dry mass) that can vary depending on topography and seasonality (Vonesh 2001, Menin et al. 2007) and the use of different diameter classes of trees. The explanation, beyond comparison, is that bamboo influences the mortality of trees, with a tendency to bend and break trees between $10 \mathrm{~cm}<\mathrm{dbh}<30 \mathrm{~cm}$ (Griscom and Ashton 2003, Silveira 2005). It was possible to check on the presence of $P$. skydmainus, which is also affected by increased density of bamboo, in contrast to habitat specialized for $P$. bambu (Arteaga-Navarro and Guayasamin 2011), which is associated with bamboo-dominated forests. These differences may reflect the bamboo species present in Ecuador (Chusquea sp.), which may have different microhabitats than those of Guadua weberbaueri, which is present in southeastern Amazonia.

The reproductive mode of frogs of the genus Pristimantis seems to minimize the importance of the presence of stagnant water bodies, suggesting that the frogs are sensitized to changes in moisture levels in the forest that influence the distribution and diversity of Pristimantis (Lynch 1980). There is no current information about the conservation status of the $P$. skydmainus and $P$. reichlei (Not Evaluated, IUCN 2013). It is important to have this information to ascertain the implications of possible human disturbances on populations of Pristimantis.

\section{Acknowledgments}

Marco Silveira and Werther Ramalho for suggestions and support. Authorization and Biodiversity Information System (SISBIO) for collecting permits (license number 37974-1). This work was supported by post-graduate fellowships from Coordenação de Aperfeiçoamento de Pessoal em Nível Superior (CAPES) and Programa de Pesquisa em Biodiversidade (PPBio) núcleo Acre to JJLR and to Paul Freed, retired Supervisor of Herpetology, Houston Zoo, Inc. for his comments and suggestions to the manuscript.

\section{References}

Allmon, W. D. 1991. A plot study of forest floor litter frogs, Central Amazon, Brazil. Journal of Tropical Ecology 7: $503-522$.

Arteaga-Navarro, A. F. and J. M. Guayasamin. 2011. A new frog of the genus Pristimantis (Amphibia: Strabomantidae) from the high Andes of Southeastern Ecuador, discovered using morphological and molecular data. Zootaxa 2876: 17-29.

Baitz, W., D. Pereira, and M. Lentini. 2008. O setor madeireiro da Amazônia brasileira. Pp. 87-104 in A. Gordon and N. Bensusan (eds.), O Manejo da Paisagem e a Paisagem do Manejo. Brasília. Instituto Internacional de Educação do Brasil.

Blair, C. and T. M. Doan. 2009. Patterns of community structure and microhabitat usage in Peruvian Pristimantis (Anura: Strabomantidae). Copeia 2009: 303-312.

Borcard, D., F. Gillet, and P. Legendre. 2011. Numerical Ecology with R. New York. Springer. 306 pp. 
Cabrera-Guzmán, E. and V. H. Reynoso. 2012. Amphibian and reptile communities of rainforest fragments: minimum patch size to support high number of species and number of individuals. Biodiversity and Conservation 21: 3243-3265.

Callefo, M. E. V. 2002. Anfíbios. Pp. 45-73 in P. Auricchio and M. G. Salomão (eds.), Técnicas de Coleta $e$ Preparação de Vertebrados para Fins Científicos $e$ Didáticos. São Paulo. Instituto Pau Brasil de História Natural.

Cardoso, A. and M. Souza. 1996. Distribuição temporal e espacial de anfíbios anuros do Seringal Catuaba, Estado do Acre, Brasil. Pp. 271-291 in J. E. Pérfaus (ed.), Herpetologia Neotropical: Actas do $2^{\text {nd }}$ Congresso Latino Americano de Herpetologia. Vol. 2. Mérida. Consejo de Publicaciones Universidad de los Andes.

Castro, W., C. I. Salimon, H. Medeiros, I. B. Silva, and M. Silveira. 2013. Bamboo number of individuals, edge effects, and tree mortality in a forest fragment in Southwestern Amazonia. Scientia Forestalis 41:159164.

Cottenie, K. 2005. Integrating environmental and spatial processes in ecological community dynamics. Ecology Letters 8: 1175-1182.

Crump, M. L. and J. R. N. J. Scott. 1994. Standard techniques of inventory and monitoring: Visual Encounter Surveys. Pp. 84-92 in W. R. Heyer, M. A. Donnelly, R. W. McDiarmid, L. A. C. Hayek, and M. S. Foster. (eds.), Measuring and Monitoring Biological Diversity Standard Methods for Amphibians. Washington. Smithsonian Institution Press.

Duarte, A. F. 2006. Aspectos da climatologia do Acre, Brasil, com base no intervalo 1971-2000. Revista Brasileira de Meteorologia 21: 308-317.

Duellman, W. E. and E. Lehr. 2009. Terrestrial-breeding frogs (Strabomantidae) in Peru. Münster. Naturund Tier-Verlag GmbH. Pp. 382.

Duellman W. E. and L. Trueb. 1994. Biology of Amphibians. Baltimore. Johns Hopkins University Press. 670 pp.

Fauth, J. E., B. I. Crother, and J. B. Slowinski. 1989. Elevational patterns of species richness, evenness, and abundance of the Costa Rican leaf-litter herpetofauna. Biotropica 21: 178-185.

Frazer, G. W., C. D. Canham, and K. P. Lertzman. 1999. Gap Light Analyzer (GLA), Version 2.0: Imaging software to extract canopy structure and gap light transmission indices from true-colour fisheye photographs, users manual and program documentation. Copyright (C) 1999: Simon Fraser University, Burnaby,
British Columbia, and the Institute of Ecosystem Studies, Millbrook, New York.

Frost, D. R. 2014. Amphibian Species of the World: an Online Reference. Version 6.0. Electronic Database accessible at http://research.amnh.org/herpetology/amphibia/index.html. American Museum of Natural History, New York, USA. Captured on 18 November 2014.

Gaston, K. J. and S. L. Chown. 2005. Neutrality and the niche. Functional Ecology 19: 1-6.

Giacomini, H. C. 2007. Os mecanismos de coexistência de espécies como vistos pela teoria ecológica. Oecologia Brasiliensis 11: 521-543.

Griscom, B. W. and P. M. S. Ashton. 2003. Bamboo control of forest succession: Guadua sarcocarpa in Southeastern Peru. Forest Ecology and Management 175: 445-454.

Griscom, B. W., D. C. Daly, and P. M. Asthton. 2007. Floristics of bamboo-dominated stands in lowland terrafirma forests of southwestern Amazonia. Journal of the Torrey Botanical Society. Lawrence 134: 108-125.

Guayasamin, J. M. and W. C. Funk. 2009. The amphibian community at Yanayacu Biological Station, Ecuador, with a comparison of vertical microhabitat use among Pristimantis species and the description of a new species of the Pristimantis myersi group. Zootaxa 2220: 41-66.

Heyer, W. R. and L. M. Hardy. 1991. A new species of frog of the Eleutherodactylus lacrimosus assembly from Amazonia, South America (Amphibia: Anura: Leptodactylidae). Proceedings of the Biological Society of Washington 104: 436-447.

Hubbell, S. P. 2001. The Unified Neutral Theory of Biodiversity and Biogeography. Princeton. Princeton University Press. 396 pp.

Hubbell, S. P. 2005. Neutral theory in community ecology and the hypothesis of functional equivalence. Functional Ecology 19: 166-172.

IUCN. 2013. The IUCN Red List of Threatened Species. Version 2013.2. Electronic Database accessible at http:// www.iucnredlist.org/. Captured 21 on November 2013.

Kneitel, J. M. and J. M. Chase. 2004. Trade-offs in community ecology: linking spatial scales and species coexistence. Ecology Letters 7: 69-80.

Laurance, W. F., L. V. Ferreira, J. M. Rankin-De Merona, and S. G Laurance. 1998. Rainforest fragmentation and the dynamics of Amazonian tree communities. Ecology 79: 2032-2040.

Legendre, P. and M. J. Fortin. 1989. Spatial pattern and ecological analysis. Vegetatio 80: 107-138. 
Legendre, P. and L. Legendre. 1998. Numerical Ecology. $2^{\text {nd }}$ edition. Amsterdam. Elsevier Science BV. 853 pp.

Lynch, J. D. 1980. A taxonomic and distributional synopsis of the Amazonian frog of the genus Eleutherodactylus. American Museum Novitates 2696: 1-24.

Macarthur, R. H. and R. Levins. 1964. Competition, habitat selection and character displacement in a patchy environment. Proceedings of the National Academy of Sciences 51: 1207-1210.

Magnusson, W. E., A. P. Lima, R. Luizão, F. Luizão, F. R. C. Costa, C. V. Castilho, and V. F. Kinupp. 2005. RAPELD: a modification of the Gentry method for biodiversity surveys in long-term ecological research sites. Biota Neotropica 5: 1-6. http://www.biotaneo tropica.org.br/v5n2/pt/abstract?point-ofview+bn 01005022005/

Manly, B .F. J. 1994. Multivariate Statistical Methods: a Primer. London. Chapman and Hall. 215 pp.

Marsh, D. M. and P. B. Pearman. 1997. Effects of habitat fragmentation on the abundance of two species of leptodactylid frogs in an Andean montane forest. Conservation Biology 11: 1323-1328.

Medeiros, H., W. Castro, C. I. Salimon, I. B. da Silva, and M. Silveira. 2013. Tree mortality, recruitment and growth in a bamboo dominated forest fragment in southwestern Amazonia, Brazil. Biota Neotropica 13: 29-34. http://www.biotaneotropica.org.br/v13n2/en/abst ract?article+bn00613022013

Menin, M., A. P. Lima, W. E. Magnusson, and F. Waldez. 2007. Topographic and edaphic effects on the distribution of terrestrially reproducing anurans in Central Amazonia: mesoscale spatial patterns. Journal of Tropical Ecology 23: 539-547.

Mikkelson, G. M. 2005. Niche-based vs. neutral models of ecological communities. Biology and Philosophy 20: $557-566$.

Oksanen, J., F. G. Blanchet, R. Kindt, P. Legendre, P. R. Minchin, R. B. O’Hara, G. L. Simpson, P. Solymos, M. H. H. Stevens, and H. Wagner. 2011. Package 'vegan'. Version 2.0-2. URL: http://cran.r-project.org/web/ packages/vegan/index.html.

Padial, J. M. and I. De la Riva. 2009. Integrative taxonomy reveals cryptic Amazonian species of Pristimantis (Anura: Strabomantidae). Zoological Journal of the Linnean Society 155: 97-122.

Pearman, P. B. 1997. Correlates of amphibian diversity in an altered landscape of amazonian Ecuador. Conservation Biology 11: 1211-1225.
Pombal, Jr. J. P. and C. F. B. Haddad. 2007. Estratégias e modos reprodutivos em anuros. Pp. 101-116 in L. B. Nascimento and P. M. E. Oliveira (eds.), Herpetologia no Brasil II. Belo Horizonte. Sociedade Brasileira de Herpetologia.

R Development Core Team. 2012. R: A Language and Environment for Statistical Computing. R Foundation for Statistical Computing, Vienna, Austria. ISBN 3-90005107-0. Version 3.1.1. URL: http://www.R-project.org/.

Ricklefs, R. E. and D. E. Schluter. 1993. Species Diversity in Ecological Communities. Chicago. University of Chicago Press. 414 pp.

Sampaio, P. R. and M. B. Souza. 2010. Amphibia, Anura, Strabomantidae, Pristimantis reichlei Padial and De la Riva, 2009: first record from Brazil, southwestern Amazonia. Check List 6: 385-386.

Segalla, M. V., Caramaschi, U., Cruz, C. A. G., Garcia, P. C. A, Grant, T., Haddad, C. F. B, and Langone, J. 2014. Brazilian amphibians - List of species. Electronic Database accessible at http://www.sbherpetologia.org.br. Sociedade Brasileira de Herpetologia, Brasil. Captured on 17 November 2014.

Silveira, M. 2005. A Floresta Aberta com Bambu no Sudeste da Amazônia: Padrões e Processos em Múltiplas Escalas. Rio Branco. Edufac. 152 pp.

Smith, M. and B. W. Nelson. 2011. Fire favours expansion of bamboo-dominated forests in the south-west Amazon. Journal of Tropical Ecology 27: 59-64.

Souza, M. B. 2009. Anfíbios: Reserva Extrativista do Alto Juruá e Parque Nacional da Serra do Divisor, Acre. Campinas. Editora do Instituto de Filosofia e Ciências Humanas. 77 pp.

Souza, V. M., M. B. Souza, and E. F. Morato. 2008. Efeitos da sucessão florestal sobre a anurofauna (Amphibia: Anura) da Reserva Catuaba e seu entorno, Acre, Amazônia sul-ocidental. Revista Brasileira de Zoologia 25: 49-57.

Thompson, R. and C. Townsend. 2006. A truce with neutral theory: local deterministic factors, species traits and dispersal limitation together determine patterns of diversity in stream invertebrates. Journal of Animal Ecology 75: 476-484.

Toral, C. E., P. Feinsinger, and M. L. Crump. 2002. Frogs and a cloud-forest edge in Ecuador. Conservation Biology 16: 735-744.

Tsuji-Nishikido, B. M. and M. Menin. 2011. Distribution of frogs in riparian areas of an urban forest fragment in Central Amazonia. Biota Neotropica 11: 63-70. http:// 
www.biotaneotropica.org.br/v11n2/pt/abstract?article+ bn01411022011.

Van Sluys, M., D. Vrcibradic, M. A. S. Alves, H. G. Bergallo, and C. F. D. Rocha. 2007. Ecological parameters of the leaf-litter frog community of an Atlantic Rainforest area at Ilha Grande, Rio de Janeiro state, Brazil. Austral Ecology 32: 254-260.

Von May, R., J. M. Jacobs, R. Santa-Cruz, J. Valdivia, J. M. Huamán., and M. A. Donelly. 2010. Amphibian community structure as a function of forest type in Amazonian Peru. Journal of Tropical Ecology 26: 509519.

Vonesh, J. R. 2001. Patterns of richness and abundance in a tropical African leaf-litter herpetofauna. Biotropica 33: 502-510.
Wake, D. B. 1991. Declining amphibian populations. Science 253: 860 .

Watling, J. I. 2005. Edaphically-biased distributions of amphibians and reptiles in a lowland tropical rainforest. Studies on Neotropical Fauna and Environment 40: $15-21$.

Wells, K. D. 2007. The Ecology and Behavior of Amphibians. Chicago. University of Chicago Press. 1400 pp.

Zimmerman, B. L. 1994. Audio strip transects. Pp. 92-97 in W. R. Heyer, M. A. Donnelly, R. W. McDiarmid, L. A. C. Hayek, and M. S. Foster (eds.), Measuring and Monitoring Biological Diversity: Standard Methods for Amphibians. Washington. Smithsonian Institution Press.

Editor: Franco Leandro Souza 